\title{
Germination and Initial Seedling Growth of Schizolobium amazonicum on Different Substrates and Irrigation Depths
}

\author{
Maria de Fátima de Castro Oliveira ${ }^{1}$ (D) 0000-0002-3153-0421 \\ Wilson Araújo da Silva ${ }^{2}$ (D) 0000-0003-4549-6815 \\ Cristiane Matos da Silva ${ }^{2}$ (D) 0000-0002-6416-4413 \\ Jhonata Santos Santana ${ }^{2}$ (D) 0000-0003-0034-3313 \\ Alinne Silva ${ }^{2}$ (D) orcid.org/0000-0003-1749-5188
}

\begin{abstract}
Due to the good silvicultural characteristics of Schizolobium amazonicum (parica) and its versatility (planting and use), the species has become an alternative in commercial exploitation. Aiming to verify the influence of irrigation depth and substrate on the germination and growth of Parica seedlings, a greenhouse experiment was conducted using randomized blocks in a $2 \times 4$ bifactorial scheme, with two types of substrates (washed sand and commercial substrate) and four irrigation depths corresponding to $50 \%, 100 \%, 150 \%$ and $200 \%$ of the reference evapotranspiration (ETo), with five replications. Germination rate, emergency speed index and biometric variables were evaluated. The commercial substrate combined with the irrigation level of $50 \%$ of ETo favored a higher emergence speed and germination rate. In the growing phase, the irrigation level of $150 \%$ of ETo combined with the commercial substrate produced better results, indicating greater survival and development in the field.
\end{abstract}

Keywords: drip, parica, seedling quality.

\section{INTRODUCTION AND OBJECTIVES}

The demand for products and services that cause minimum impact to the environment has been a recurring theme in recent years, highlighting the use of planted forests. According to Indústria Brasileira de Árvores (IBÁ, 2016), only 90,047 hectares of Parica plantations (Schizolobium amazonicum Huber ex Ducke) were distributed in the states of Pará, Maranhão and Tocantins in 2015, applied to the production of laminated wood and plywood, linings, toothpicks, paper, furniture, finishing and frames (ABRAF, 2013).

According to Almeida et al. (2013), the species has been among reforested species in Brazil, as it has increases in height and diameter that allow its use after planting with similar time to exotic species. Melo et al. (2014) emphasize its high yield in lamination, equating to Pinus and Eucalyptus genus, already traditional in this sector.

Due to the expansion of forest plantations and consequent increase in the demand for seedlings production, studies that assess the influence of factors such as availability of water, light and nutrients for developing seedling production technology are essential to ensure the success of the forest sector. Among these factors, the availability of water and substrate are limiting factors in seedling production, as their excess and/or absence is harmful.

According to Thebaldi et al. (2016), when irrigation is performed through a well-sized and operated system, it allows the seeds to express all their genetic potential. Gondin et al. (2015) highlight the influence of substrate on producing forest seedlings. According to the authors, they observed sand and sawdust provided good results in addition to commercial products when testing different substrates in producing Parica seedlings, and also reduced costs to the producer.

Considering that water is an essential resource for seedling quality, and that the type of species as well as the substrate used alter the amount of water to be applied during the seedling production, the objective of this study was to analyze the influence of irrigation and substrates on

\footnotetext{
${ }^{1}$ Universidade Estadual do Maranhão (UEMA), Balsas, MA, Brasil

${ }^{2}$ Universidade Estadual da Região Tocantina do Maranhão (UEMASUL), Imperatriz, MA, Brasil
} 
the germination and growth of Parica seedlings in Imperatriz, Maranhão, Brazil.

\section{MATERIALS AND METHODS}

The present study was conducted at the Technological Diffusion Center (CDT) of Empresa Brasileira de Infraestrutura Aeroportuária (Infraero) in the city of Imperatriz, in the state

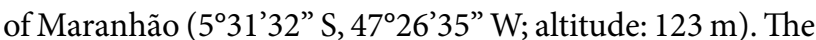
climate is classified as Aw (according to Koppen), hot and humid tropical.

The experiment was installed in a greenhouse with a usage area of $24 \mathrm{~m}^{2}$, covered with plastic and $50 \%$ sombrite over the greenhouse. The bags with the seedlings were arranged on a wooden platform to avoid contact with the soil.

Due to the necessity of each irrigation line to apply a single flow and to not allow any volume variation in each plant, a block designation was necessary even though it was a greenhouse experiment. Thus, the experiment was installed in a randomized complete block design (RBC) in a $2 \times 4$ bifactorial scheme consisting of two substrate compositions (S1 and S2), with S1 being washed sand and S2 commercial substrate composed of a mixture of pine bark and coconut fiber, as well as four irrigation levels (L1, L2, L3 and L4) corresponding to 50\%, 100\%, 150\% and $200 \%$ of the reference evapotranspiration (ETo), with five replications, totaling 40 experimental units.

Each repetition was initially composed of three seeds that were thinned after germinating and computed for the germination percentage calculation, leaving only one plant per experimental unit.

The estimation of the ETo was by the Penman-MonteithFAO method, using a historical series observation of 46 years (1969 to 2015) of the National Institute of Meteorology (Inmet). The climatic data were obtained from a meteorological station located $3,700 \mathrm{~m}$ from the experiment site.

Temperature and relative humidity of the air inside the oven were measured with a digital thermohygrometer. The average results were $34.3^{\circ} \mathrm{C}$, with a maximum of $34.5^{\circ} \mathrm{C}$ and a minimum of $31.0{ }^{\circ} \mathrm{C}$, and $64 \%$ of relative humidity.

The seeds used in the production of the seedlings were purchased at Parica Research Center (CPP). In the asepsis process, the seeds were immersed in $5 \%$ sodium hypochlorite solution, then washed in running water and placed on paper towel to dry.
The method used to overcome dormancy was to cut the tegument surface with a pair of pliers on the side opposite the hilum in order to promote imbibition.

The sowing was done manually in polyethylene bags $(15 \mathrm{~cm} \times 30 \mathrm{~cm})$ with three seeds per bag until germination stabilization, with posterior thinning, leaving only the most vigorous seedling per pot.

An automatic drip irrigation system was used to apply the irrigation water depths with lines composed of self-compensating drippers that enabled flow regulation. One dripper was set per seedling with a frequency of two irrigations a day; one in the morning at $5 \mathrm{a} . \mathrm{m}$., and another at the end of the afternoon at 5 p.m. with a duration of 5 minutes each watering.

Adjustments of the applied water depths corresponding to $50 \%, 100 \%, 150 \%$ and $200 \%$ of the ETo were done by individual registers at the beginning of each irrigation line. The bags were arranged in a way aligned to the drippers so that the drop was applied to the center of each pot.

The volumes of the applied water depths were adjusted to the area of the pots to be irrigated, to the irrigation frequency of twice a day and an application time of $5 \mathrm{~min}$. Adjustments of the irrigation lines were performed with a rain gauge and a timer, both of which were used to calibrate the water volume applied per minute corresponding to each treatment.

The total volume of water applied per seedling during the experiment was $0.95 \mathrm{~L}, 1.90 \mathrm{~L}, 2.85 \mathrm{~L}$ and $3.80 \mathrm{~L}$ for the $50 \%, 100 \%, 150 \%$ and $200 \%$ water depths, respectively.

The evaluated variables in each experimental unit were: germination rate (GR), total emergency speed index (ESI), plant height $(\mathrm{H})$, stem diameter (SD), number of leaves (NL), shoot fresh mass (SFM), shoot dry mass (SDM), root fresh mass (RFM), root dry mass (RDM), height/ diameter ratio (H/D), Dickson Quality Index (DQI) and water use efficiency (WUE). The GR and ESI measurements were performed from germination to stabilization, while measurements of H, SD, NL, SFM, SDM, RFM, RDM, H/D, DQI and WUE were performed at 28 days after seeding.

The GR variable was obtained by counting the plants germinated by the total number of seeds planted, being those for which cotyledons and hypocotyls were above the substrate surface (Brazil, 2009). For the ESI calculation, daily counts of the number of emerged seedlings were performed starting from the emergence of the first seedling. The evaluations were carried out until the last count and the ESI calculation was done by the sum of the division of the emerged plants by the day number of the sowing. 
The $\mathrm{H}$ variable was determined using a graduated ruler from the plant base to the apical bud, the SD using a digital caliper, the NL by counting, the SFM and RFM variables were obtained by weighing the samples at the collection time on a precision scale, and the SDM and $\mathrm{RDM}$ were obtained after drying in a forced-circulation air oven until constant weight was reached at $60^{\circ} \mathrm{C}$ and then weighing the final material. The weighings were done on a precision scale of 0.0001 . The Dickson quality index (DQI) was calculated using Equation 1:

$$
\mathrm{DQI}=\mathrm{TDM}(\mathrm{g}) \div\left(\frac{\mathrm{H}(\mathrm{cm})}{\mathrm{SD}(\mathrm{mm})}-\frac{\mathrm{SDM}(\mathrm{g})}{\mathrm{RDM}(\mathrm{g})}\right)
$$

In which TDM: total dry mass, obtained by the sum of SDM and RDM; H: height; SD: stem diameter; SDM: shoot dry mass, and RDM: root dry mass.

Water use efficiency (WUE) was determined from the relationship between the dry matter mass and the water consumption of the plant (Jabro et al., 2012; Silva et al., 2012) according to Equation 2, described below:

$$
\mathrm{WUE}=\frac{\mathrm{TDM}}{\mathrm{TWc}}
$$

In which, WUE: water use efficiency, $\mathrm{kgha}^{-1} \mathrm{~mm}^{-1}$; TDM: total dry mass, $\mathrm{kgha}^{-1}$; TWc: total water consumption, $\mathrm{mm}$.

As this was an experiment with factors composed by quantitative and qualitative treatments, regression analysis was performed for the quantitative and qualitative treatments, analysis of variance and means test by Tukey's test at $5 \%$ of probability, using Assistat 7.6 statistical software.

\section{RESULTS AND DISCUSSION}

\subsection{Germination phase}

Germination started at 6 days after sowing (DAS), reaching the maximum germination point at 7 DAS, decreasing in the next few days until stabilization of the germination at 11 days.

The experiment GR was $90 \%$, a similar value to that found by Dapont et al. (2014), which promoted dormancy break by scarification with puncture $(89 \%)$ and water at $100{ }^{\circ} \mathrm{C}(91 \%)$, and by Cruz et al. (2007) under immersion treatment in sulfuric acid for 60 minutes (92\%). This result is higher than the germination rates by sanding (85\%) (Dapont et al., 2014). Thus, the technique of cutting the seed coat for Parica seeds is efficient in detriment to other more complex techniques and difficult to perform in the field or nursery.

We found that the GR in the commercial substrate was higher between 6 and 7 DAS in all the evaluated irrigation water depths, while the maximum GR increases for the seedlings produced in washed sand were observed between 7 and 10 DAS for the $50 \%$ and $150 \%$ water depths, and between 6 and 7 DAS for the $100 \%$ and $200 \%$ water depths, demonstrating the influence of the substrate composition on moisture retention and consequently on GR.

GR was higher in the commercial substrate for most applied irrigation water depths, except for the $200 \%$ water depths and washed sand combination, which promoted greater GR than the combination of $200 \%$ water depths and commercial substrate at 10 days. This result is attributed to the fact that the washed sand-based substrate provided better natural drainage (Figure 1d).

The treatment with commercial substrate promoted $100 \%$ germination at 7 DAS on the $50 \%$ water depth (Figure 1a), while this result was reached on day 10 for the $100 \%$ water depth (Figure 1b), and on day 11 for $150 \%$ water depth (Figure 1c).

The commercial substrate treatment maintained a higher emergence speed for all tested water depths, with an ESI of 2.2 for the $50 \%, 100 \%$ and $150 \%$ reference evapotranspiration (ETo) water depth, and 2.0 for the water depth with $200 \%$ reference evapotranspiration (ETo). This result can be justified by the best physical characteristics found in the commercial substrate (texture, structure, porosity and apparent density) that favor better germination and seedling production.

The decrease in ESI with increasing irrigation intensity was also found by Alves et al. (2015) - they verified that temporary water surplus in the substrate affected the gas exchange of the soil, reducing the biochemical reactions of the embryo in Parica seeds.

The best results for the washed sand treatment were observed in the $100 \%$ and $200 \%$ water depths, where there was $93.3 \%$ and $100 \%$ germination, respectively. This fact suggests no correlation between the intensity of the applied irrigation water depths and the increase in the germination rate in this substrate. 
(a)

$$
\text { GR/day - Water depth } 1
$$
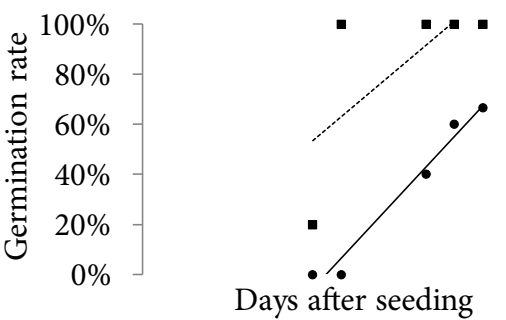

Days after seeding

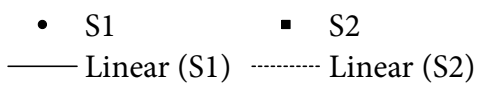

(c)

$$
\text { GR/day - Water depth } 3
$$

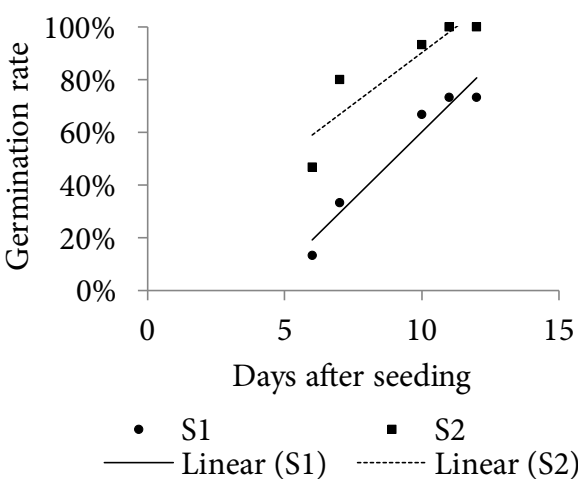

(b)

GR/day - Water depth 2
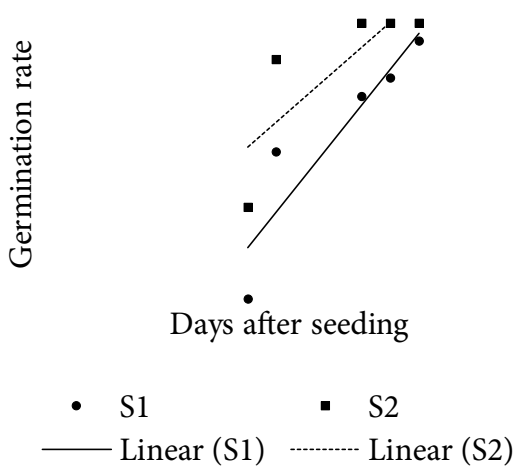

(d)

GR/day - Water depth 4

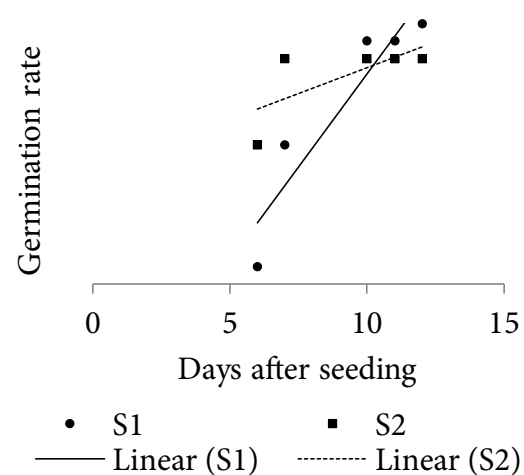

Figure 1. Germination curve of Schizolobium amazonicum seeds sown on different substrates (washed sand and commercial substrate) and submitted to different irrigation water depths corresponding to 50\% of ETo (a), 100\% of ETo (b), $150 \%$ of ETo (c), and 200\% of ETo (d).

\subsection{Growth phase}

The results of the analyzes showed that there were no statistical differences for the treatments for the SD variable, meaning that regardless of the combination between the water depths and the substrate used there was no significant influence on the stem diameter at 28 DAS (Table 1 ).

In all the other evaluated variables, the mean test showed superior results for the commercial substrate (Table 1). This result can be attributed to the physical and chemical characteristics of the substrate to the detriment of the washed sand, which does not present conditions for the full development of the plant.

In addition, the nutrients in the commercial substrate increased the variables because it is a pioneer species that responds very well to fertilization. This was also observed by Sabonaro \& Galbiatti (2011) in Schizolobium parahyba species that presented significant differences for the parameters of height, $\mathrm{H} / \mathrm{D}$ and DQI with the addition of an organic compound in the studied substrates. Also, in studying Schizolobium amazonicum Araújo et al. (2017) verified higher seedling growth in substrates with higher proportions of organic compounds.

Table 1. Analysis of means of the variables at 28 DAS.

\begin{tabular}{cccccccc} 
Substrate & $\begin{array}{c}\text { SD } \\
(\mathbf{m m})\end{array}$ & $\begin{array}{c}\text { NL } \\
(\mathbf{Q t d})\end{array}$ & $\begin{array}{c}\text { RFM } \\
(\mathbf{g})\end{array}$ & $\begin{array}{c}\text { SFM } \\
(\mathbf{g})\end{array}$ & $\begin{array}{c}\text { RDM } \\
(\mathbf{g})\end{array}$ & $\begin{array}{c}\text { SDM } \\
(\mathbf{g})\end{array}$ & $\begin{array}{c}\text { DQI } \\
\text { S1 }\end{array}$ \\
\hline S2 & $2.9300 \mathrm{a}$ & $2.7000 \mathrm{~b}$ & $1.7650 \mathrm{~b}$ & $2.2000 \mathrm{~b}$ & $0.1910 \mathrm{~b}$ & $0.5620 \mathrm{~b}$ & $0.0953 \mathrm{~b}$ \\
\hline
\end{tabular}

SD: stem diameter; NL: number of leaves; RFM: root fresh mass; SFM: shoot fresh mass; RDM: root dry mass; SDM: shoot dry mass; DQI: Dickson quality index; S1: sand; S2: commercial substrate. The averages followed by the same lowercase letter in the column do not differ statistically from each other by the Tukey's test ( $p>0.05)$. 
The DQI is the most complete indicator in the quality representation of seedlings because it relates several important parameters in this evaluation, such as the proportions between masses of total dry matter, root and shoot dry matter and $\mathrm{H} / \mathrm{SD}$ index that reflects the biomass accumulation, the greater resistance and better fixation of the seedlings in the soil (Caldeira et al., 2012; José et al., 2009).

The DQI averages ranged from 0.01 for the washed sand to 0.16 for the commercial substrate (Table 1), indicating the seedlings planted on commercial substrate had higher quality than those planted in washed sand, which showed a higher probability of survival and growth after planting, which in turn will result in a decrease in cultural practices and stand maintenance.

The results obtained in this study for the commercial substrate were superior to those presented by Vieira et al. (2014) at 120 days, where they produced Parica seedlings in a $100 \%$ soil treatment and found DQI $=0.10$. It is lower than that found by the same authors when using commercial substrate (DQI 0.27). It is worth mentioning that the higher the DQI value, the better the produced seedling quality, since these seedlings will generally have higher values of SD, SDMA, RDM and TDM.

When evaluating the irrigation water depths, the results showed that there was no influence on the parameters $\mathrm{H}, \mathrm{SD}$, DQI, SFM and SDM. This fact can be attributed to its low water requirement and the ability of Parica to have efficient osmoregulation mechanisms that favor biomass survival, growth and formation, even in water deficit (Carvalho, 2005). Although the influence of the water depths was not significant for these indicators, the highest averages were observed in the water depth treatment of $150 \%$.

The fresh root mass presented the best treatment results for the $150 \%$ water depth (Figure 2a), while the mean values for root dry weight were similar for the $150 \%$ and $200 \%$ water depths (Figure $2 b$ ). The results for NL were similar in the $50 \%$ and $150 \%$ water depths (Figure 2c). These results corroborate those found by Sabonaro \& Galbiatti (2011), who also found significant differences in applying irrigation water depth of $150 \%$ ETo to Schizolobium parahyba seedlings for these variables.

It is worth mentioning that although the irrigation depth corresponding to $150 \%$ of ETo presented the best results for RFM and RDM in both substrates, this does not rule out the possibility of specific water management due to the different water retentions provided by the composition of each type of substrate.

There was a significant interaction between the water depths and substrate factors in the $\mathrm{H}$ variable and in the H/SD ratio (Table 2), with the commercial substrate being statistically superior in both indicators, reaffirming the DQI result and the highest mean values verified in the $150 \%$ water depth.

The ratio of height and stem diameter (H/SD) is a good parameter to be used in the quality of seedlings because it is simple and practical to perform, in addition to not requiring destruction of the material. José et al. (2009) recommend that the result of this division be less than 10 for forest species, while Carneiro (1995) places the limits of this indicator between 5.4 and 8.1 .

Considering these limits presented by the authors, all the seedlings produced with the commercial substrate have a good quality standard, and with an even better result when combined with the $150 \%$ water depth (mean of 6.6) (Table 2); a result similar to that found by Araújo et al. (2017) when producing Parica seedlings in organic compound (average $=6.35$ ).

The water use efficiency (WUE) results are shown in Table 3. The highest water volume ratio applied per dry matter produced was found in treatments with a $50 \%$ water depth, regardless of the substrate used. This result indicates that Parica is a species that has tolerance strategies to water stress. This result corroborates Duarte (2014), who observed that this species is tolerant to water stress, presenting defense mechanisms such as reduced perspiration and increased carotenoids in stress situations.
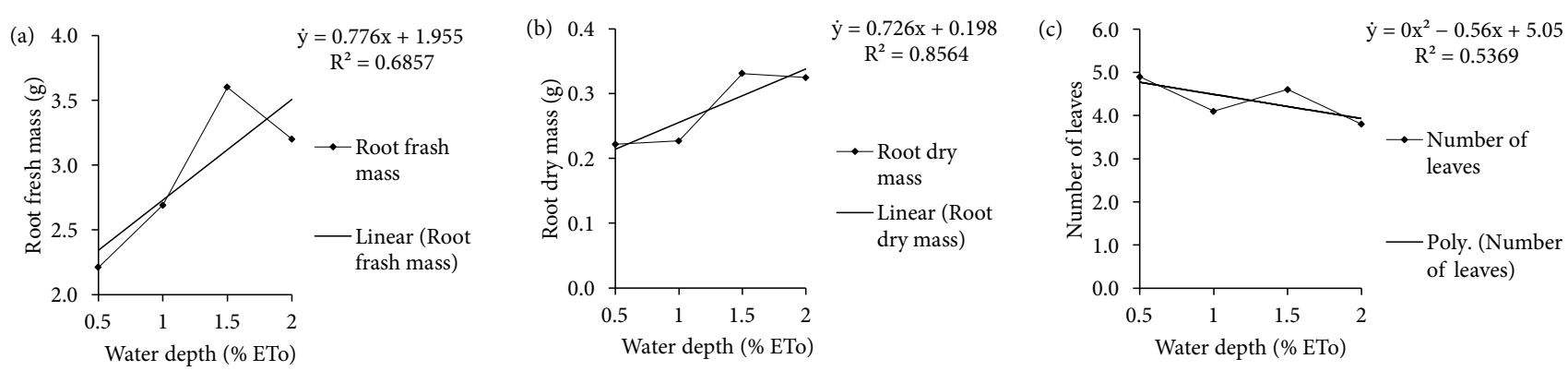

Figure 2. Response of (a) root fresh mass (g); (b) root dry mass (g); (c) number of leaves variables under different irrigation depths. 
Table 2. Averages of height and H/SD variables according to the different types of substrates and depths.

\begin{tabular}{ccccc} 
Substrate & \multicolumn{4}{c}{ Height means } \\
\cline { 2 - 5 } S1 & L1 & L2 & L3 & $14.9000 \mathrm{Ba}$ \\
S2 & $13.6000 \mathrm{bA}$ & $13.7000 \mathrm{bA}$ & $15.5000 \mathrm{bA}$ & $21.1000 \mathrm{Aa}$ \\
Substrate & $19.7000 \mathrm{aA}$ & $18.8000 \mathrm{aA}$ & $22.0000 \mathrm{aA}$ & L4 \\
\cline { 2 - 5 } S1 & L1 & L2 & L3 & $4.9250 \mathrm{Aa}$ \\
S2 & $4.6884 \mathrm{bA}$ & $4.2676 \mathrm{bA}$ & $4.8433 \mathrm{bA}$ & $6.3222 \mathrm{aA}$ \\
\hline
\end{tabular}

S1: sand substrate; S2: commercial substrate; L1: water depth with 50\% ETo; L2: water depths with 100\% ETo; L3: water depth with 150\% ETo; L4: water depths with $200 \%$ ETo. SDM for columns $=4.7528$. The averages followed by the same lowercase letter in the column and upper case in the row do not differ statistically from each other by the Tukey's Test $(p>0.05)$.

Table 3. Efficiency of water use (WUE) $\mathrm{kgha}^{-1} \mathrm{~mm}^{-1}$ for sand (S1), commercial substrate (S2) and irrigation water depths of 50\% (L1), $100 \%$ (L2), $150 \%$ (L3) and $200 \%$ (L4).

\begin{tabular}{ccccc} 
& L1 & L2 & L3 & L4 \\
\hline S1 & 7.07 & 3.64 & 2.95 & 2.12 \\
S2 & 11.81 & 7.67 & 5.61 & 3.67 \\
\hline
\end{tabular}

\section{CONCLUSIONS}

The commercial substrate together with the irrigation depth of $50 \%$ ETo favored a higher emergence speed and germination rate for Parica seeds.

For growth, it is recommended to use an irrigation water depth with $150 \%$ of the ETo together with the commercial substrate as this favored better results for $\mathrm{D}, \mathrm{H}, \mathrm{H} / \mathrm{D}, \mathrm{DQI}$, RDM, RFM, SDM and SFM, thereby leading to better survival and development in the field.

\section{ACKNOWLEDGEMENTS}

To Fundação de Amparo à Pesquisa e ao Desenvolvimento Científico e Tecnológico do Maranhão (FAPEMA) and Universidade Estadual da Região Tocantina do Maranhão (UEMASUL).

\section{SUBMISSION STATUS}

Received: 17 Oct. 2017

Accepted: 31 July 2018

Associate editor: José Henrique Tertulino Rocha

\section{CORRESPONDENCE TO}

\section{Wilson Araújo da Silva}

Universidade Estadual da Região Tocantina do Maranhão (UEMASUL), Rua Godofredo Viana, 1.300, CEP 65900-000, Imperatriz, MA, Brasil e-mail: wilsonufrrj@yahoo.com.br

\section{REFERENCES}

Almeida DH, Scaliante RM, Macedo LB, Macêdo AN, Dias AA, Christoforo AL et al. Caracterização completa da madeira da espécie amazônica Paricá (Schizolobium amazonicum HERB) em peças de dimensões estruturais. Revista Árvore 2013; 37(6): 1175-1181. 10.1590/S0100-67622013000600019

Alves JDN, Moreira WKO, Oliveira SS, Leão FAN, Okumura RS. Taxa e índice de velocidade de emergência de paricá em diferentes substratos e frequência de irrigação. Enciclopédia Biosfera 2015; 11(21): 1766-1773.

Araújo EF, Aguiar AS, Arauco AMS, Gonçalves EO, Almeida KNS. Crescimento e qualidade de mudas de paricá produzidas em substratos à base de resíduos orgânicos. Nativa 2017; 5(1): 1623. 10.5935/2318-7670.v05n01a03

Associação Brasileira de Florestas Plantadas - ABRAF. Anuário estatístico ABRAF 2013: ano base 2012. Brasília, DF: ABRAF; 2013.

Brazil. Ministério da Agricultura, Pecuária e Abastecimento. Regras para análise de sementes. Brasília, DF: Mapa; 2009.

Caldeira MVW, Delarmelina WM, Lube SG, Gomes DR, Gonçalves EO, Alves AF. Biossólido na composição de substrato para a produção de mudas de Tectona grandis. Revista Floresta 2012; 42(1): 77-84. 10.5380/rf.v42i 1.26302

Carneiro JGA. Produção e controle de qualidade de mudas florestais. Curitiba: UFPR; 1995.

Carvalho CJR. Respostas de plantas de Schizolobium amazonicum [S. parahyba var. amazonicum] e Schizolobium parahyba [Schizolobium parahybum] à deficiência hídrica. Revista Árvore 2005; 29(6): 907914. 10.1590/S0100-67622005000600009

Cruz ED, Carvalho JEU, Queiroz RJB. Scarification with sulphuric acid of Schizolobium amazonicum Huber ex Ducke seeds Fabaceae. Scientia Agricola 2007; 64(3): 308-313. 10.1590/S010390162007000300017

Dapont EC, Silva JB, Oliveira JD, Alves CZ, Dutra AS. Métodos para acelerar e uniformizar a emergência de plântulas de Schizolobium amazonicum. Revista Ciência Agronômica 2014; 45(3): 598-605.

Duarte DM. Crescimento de mudas de paricá submetidas à desfolha e ao déficit hídrico. Ipameri: UEG; 2014. 
Gondin JC, Silva JB, Alves CZ, Dutra AS, Elias L Jr. Emergência de plântulas de Schizolobium amazonicum Huber ex Ducke (Caesalpinaceae) em diferentes substratos e sombreamento. Revista Ciência Agronômica 2015; 46(2): 329-338. 10.5935/1806-6690.20150012

Indústria Brasileira de Árvores - IBÁ. Relatório anual [Internet]. Brasília, DF: IBÁ; 2016 [cited 2017 May 23]. Available from: https:// bit.ly/2H4GLBJ

Jabro JD, Iversen WM, Evans RG, Stevens WB. Water use productivity of sugarbeet, malt barley, and potato as affected by irrigation frequency. Agronomy Journal 2012; 104(6): 1510-1516. 10.2134/agronj2012.0169

José AC, Davide AC, Oliveira SL. Efeito do volume do tubete, tipo e dosagem de adubo na produção de mudas de aroeira (Schinus terebinthifolia Raddi). Agrarian 2009; 2(3): 73-86.

Melo RR, Menezzi CHS, Pavan BE, Rodolfo F Jr. Rotary peeling yield of Schizolobium amazonicum (Leguminosae - Caesalpinioideae). Acta Amazonica 2014; 44(3): 315-320. 10.1590/1809-4392201302926
Sabonaro DZ, Galbiatti JA. Seedling growth of Schizolobium parahyba on different substrates and irrigation levels. Rodriguésia 2011; 62(3): 467-475. 10.1590/2175-7860201162303

Silva AO, Soares TM, Silva EFF, Santos NA, Klar AE. Consumo hídrico da rúcula em cultivo hidropônico NFT utilizando rejeitos de dessalinizadores em Ibimirim-PE. Brazilian Journal of Irrigation and Drainage 2012; 17(1): 114-125. 10.15809/ irriga.2012v17n1p114

Thebaldi MS, Lima LA, Silva AC, Colares MFB, Lima PLT. Eficiência de sistemas de irrigação em mudas de espécies florestais nativas produzidas em tubetes. Ciência Florestal 2016; 26(2): 401-410. 10.5902/1980509822741

Vieira CR, Weber OLS, Scaramuzza JF. Estudo de resíduos orgânicos como substrato para a produção de mudas de paricá. Revista de Ciências Ambientais 2014; 8(2): 47-60. 10.18316/1652 